with white matter abnormalities in the Women's Health Initiative Memory Study (WHIMS)-MRI trial. J Clin Hypertens 2010; 12: 203-12.

39 McGuinness $B$, Todd $S$, Passmore $P$, Bullock R. Blood pressure lowering in patients without prior cerebrovascular disease for prevention of cognitive impairment and dementia. Cochrane Database Syst Rev 2009; 4: CD004034.

40 Peters R, Beckett N, Forette F, Tuomilehto J, Clarke R, Ritchie C, et al. Incident dementia and blood pressure lowering in the Hypertension in the Very Elderly Trial cognitive function assessment (HYVET-COG): a double-blind placebo controlled trial. Lancet Neurol 2008; 7: 683-9.
41 Lazarus R, Prettyman R, Cherryman G. White matter lesions on magnetic resonance imaging and their relationship with vascular risk factors in memory clinic attenders. Int J Geriatr Psychiatry 2005; 20: 274-9.

42 Thomas AJ, O'Brien JT, Davis S, Ballard C, Barber R, Kalaria RN, et al. Ischemic basis for deep white matter hyperintensities in major depression: a neuropathological study. Arch Gen Psychiatry 2002; 59: 785-92.

43 Waldstein SR, Wendell CR, Lefkowitz DM, Siegel EL, Rosenberger WF, Spencer RJ, et al. Interactive relations of blood pressure and age to subclinical cerebrovascular disease. J Hypertens 2012; 30: 2352-6.

\title{
Irmfried Eberl: psychiatry and the Third Reich
}

\section{Ciaran Somers}

Dr Irmfried Eberl, Austrian and member of the National Socialist German Workers (NAZI) party was appointed in 1939 as head of the Brandenburg Psychiatry Facility, despite limited training and experience in psychiatry. In 1940 he commenced coordination of mass killing of mentally ill patients there as part of the T4 euthanasia programme: 9772 patients were killed at Brandenburg and 8601 at Bernberg, another facility under his control.

Holding the rank of SS Obersturmführer, Eberl was commissioned in 1942 with the preparation of the Treblinka concentration camp for ethnic cleansing of Jews and other minorities, the only physician to hold such a command under the Nazis. His enthusiasm to increase the throughput of Treblinka ultimately resulted in his dismissal as commandant, as the disposal of the bodies fell significantly behind, creating a cremation backlog. He was charged with war crimes in 1947 but hanged himself while awaiting trial.

Close to 300000 patients with schizophrenia were either sterilised or killed in Nazi Germany. Of 600-700 psychiatrists practising there at the time, it is unclear how many refused to participate or protested. A few, including Hans Creutzfeldt, protested publicly.

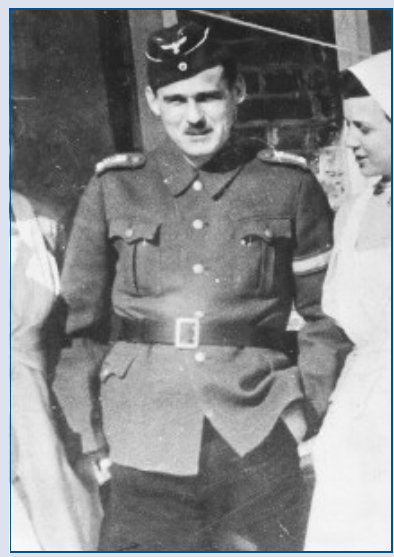

Dr Irmfried Eberl

Source: www. whale.to/b/irmfried_eberl.html

The gas chamber as a method of mass killing originated in German psychiatric hospitals. Economic factors were the main reason given by the Nazis - their propaganda campaign reported that maintaining one 'life-unworthy retard' in an asylum would support 40 poor families. Hitler in 1941 granted immunity from prosecution for medical staff who subjected their mentally ill patients to euthanasia. Strict 'criteria' were laid down to qualify, including a diagnosis of schizophrenia and criminal insanity. The assessors for the T4 programme included Werner Villinger, Friedrich Mauz and Friedrich Panse, all three subsequent presidents of the Society of German Neurologists and Psychiatrists (GDNP) in the postwar years. Before they were killed many of the patients were used for research, including Carl Schneider's (professor of psychiatry at Heidelberg University) experiments on mentally ill children.

When the war ended a collective denial descended on German psychiatry. Professor Werner Heyde, medical director of the T4 programme, enjoyed a second career as a court-appointed medical expert in Schleswig-Holstein, under an assumed name. Many in both the medical and legal professions were aware of his real identity. In 1945 Professor Gerhard Schmidt, former director of the psychiatric clinic in Lübeck, gave a radio talk about the crimes committed against the mentally ill. For 20 years he was unable to find a publisher for the manuscript on the topic, as many psychiatrists were afraid that publication of the details of these crimes would prevent efforts to rebuild the profession.

Government legislation also reflected this denial. In 1965, the revised Federal Indemnification Law provided for the indemnification of victims of Nazi crimes, but excluded those who had been forcibly sterilised as it was argued they had not been persecuted for reasons of race. Some of the expert witnesses for the Bundestag's Restitution Committee in the 1960s had themselves participated in the forced sterilisations and killings during the Third Reich. Werner Villinger rejected the idea of compensation payments on the grounds that they might cause the victims to develop 'neurotic ailments'. The Nazi-enacted Law for the Prevention of Hereditary Diseased Offspring was finally repealed in 2007. The Federal Indemnification Law remains unchanged, meaning that the mentally ill have not been explicitly acknowledged as victims of the Nazi regime. In 2010 Professor Frank Schneider, president of the German Association for Psychiatry and Psychotherapy (DGPPN), acknowledged that with just a few exceptions a large majority of German psychiatrists took part in planning, implementing and creating scientific legitimacy for sterilisation and murder under the Nazi regime. He apologised to the victims and their relatives for the pain and injustice they endured at the hands of German psychiatrists during that period and for the subsequent silence, trivialisation and denial that had characterised psychiatry in postwar Germany.

Schneider F. Psychiatry under National Socialism - Remembrance and Responsibility. DGPPN, 2010. Available at: https://www.dgppn.de/history/ psychiatry-under-national-socialism/speech-professor-schneider.html (accessed May 2014).

Additional reading:

Fuller Torrey E, Yolken RH. Psychiatric genocide: Nazi attempts to eradicate schizophrenia. Schizophr Bull 2010; 36: 26-32.

Strous RD. Dr. Irmfried Eberl (1910-1948): mass murdering MD. Isr Med AssoC J 2009; 11: 216-8. 